\title{
INCOME STRUCTURE AND PERFORMANCE: AN EMPIRICAL ANALYSIS OF ISLAMIC AND CONVENTIONAL BANKS IN INDONESIA
}

\author{
Mohsin Ali* and Mudeer Ahmed Khattak** \\ *Taylor's Business School, Taylor's University, Malaysia. \\ **Universiti Kuala Lumpur Business School, Universiti Kuala Lumpur, Malaysia.
}

\begin{abstract}
Banks have tried to compensate for the decline in their profits due to increased competition by shifting their focus toward non-intermediation activities. This paper assesses the impact of these non-intermediation activities on the profitability and risk of Islamic and conventional banks in Indonesia. We use a system generalized method of moments estimator to control for the simultaneity for all the banks in our sample for the period from 2007 to 2017. Our results suggest that non-intermediation income has a positive impact on bank performance. We find no difference between Islamic and conventional banks in terms of the link between non-intermediation income and performance.
\end{abstract}

Keywords: Profitability; Risk; Non-intermediation income; Indonesia.

JEL Classifications: G21; G28.

Article history:

Received : July 3, 2019

Revised : October 30, 2019

Accepted : : December 2, 2019

Available online : January 31, 2020

https://doi.org/10.21098/bemp.v23i0.1193 


\section{INTRODUCTION}

Banks have always been perceived as an intermediary (Zhang, 2010) but, as competition increases, their share of traditional activities has been gradually decreasing, especially in developed markets (Allen and Santomero, 2001). This period could also be termed as the era of financial deregulation. Banks have no choice but to become more innovative to survive in the marketplace. Banks have therefore started moving toward nontraditional banking activities. This means banks will have different sources of income, i.e., income from both traditional and nontraditional activities. At the micro level, different income sources are expected to stabilize the operating income of banks, because nontraditional activities are assumed to be uncorrelated with traditional banking activities (Chiorazzo et al., 2008). However, there are arguments against this strategy as well. For instance, DeYoung and Roland (2001) propose that income from nontraditional activities could have larger variations because switching to other banks for these activities is easier than pure traditional activities.

In the recent past, the non-intermediation activities of banks have attracted a great deal of attention, with a broad spectrum of studies focusing on the connection between nontraditional banking activities and bank profitability or risk. Most of the literature is limited to developed countries or the perspective of non-financial industries. The literature on the impact of income diversification effects on the banking industry is relatively inadequate, especially when it comes to developing countries. Due to different market structures and institutional settings, developing countries could offer a different snapshot of the linkage between nontraditional banking activities and bank performance. The literature has shown that the banking industry in developing countries has been operationally less efficient. Following resource base theory, diversification could boost a firm's operating efficiency, increase its debt capacity, and decrease its taxes (Zahavi and Lavie, 2013). On the other hand, the literature also suggests that diversified firms could increase their discretionary resources to assume value-decreasing investments, take on too many investments in fixed assets, and lack focus on revenue generation (Fauver et al., 2003). This makes the impact of banks' income diversification strategy worth investigating in the case of developing markets.

We choose to study this impact for the case of Indonesia, one of the fastest growing developing economies. Banks are the predominant source of business finance in most developing countries, including Indonesia (Moyo et al., 2014). The Indonesian banking sector also provides a good mix of Islamic and conventional banks, which makes this study more interesting. According to Bank Indonesia, Islamic banking assets have experienced a growth rate of $65 \%$ over the last five years (2012-2017). Islamic banking promotes an alternative form of financial intermediation in these countries. Besides intermediation, just like their conventional peers, Islamic banks offer fee-based services for economic activities. Income generation from non-intermediation activities is expected to affect the risk and returns of Islamic banks differently compared to intermediation-based activities. It would therefore be interesting to see how different the impact is on Islamic banks, compared to their conventional counterparts.

We investigate the following research questions: (1) whether income from nontraditional sources has an impact on bank profitability in Indonesia, (2) whether 
income from nontraditional sources affects bank risk in Indonesia, and (3) whether the impact of income from nontraditional sources on profitability and risk varies due to differences between Islamic and conventional banking models. For the purposes of this study, we utilize a generalized method of moments (GMM) estimation approach on a sample of 121 Indonesian banks (113 conventional and eight Islamic banks) covering the period 2007-2017. We use system GMM to control for the simultaneity for all the banks in our sample. We find our results to be robust after conducting robustness tests using different methods and proxies.

Our findings suggest that non-intermediation income has a positive impact on bank performance. This indicates that banks with greater income diversification tend to perform better. Moreover, non-Intermediation activities are found to increase returns on assets, regardless of bank size, whereas big banks seem to enjoy higher returns on equity. The relationship between non-intermediation income and bank performance is the same for both Islamic and conventional banks.

We extend the literature in several ways. First, we broaden the study of nontraditional activities, conducted mainly on US and European commercial banks, by investigating Indonesian banks. Second, earlier studies focus on either bank performance or risk, whereas our study examines simultaneously the impact of non-intermediation activities on profitability and risk and is thus a more comprehensive analysis. Third, most of the previous research focuses only on conventional banks and rarely considers other, alternative forms of banking, such as Islamic banks-except for Shahimi et al. (2006) and Karakaya and Er (2013) for the cases of Malaysia and Turkey, respectively. Our study investigates whether the effect of non-interest/financing activities differs between Islamic and conventional banks in Indonesia. Fourth, our study contributes to the literature on diversification in Islamic finance, where the choice between only equity and debt modes of financing remains a burning argument (Sadique, 2010).

This paper is organized as follows. Section II briefly reviews the literature. Section III describes the econometric model, data, and methodology. In Section IV, we discuss the empirical results. The final section, Section $\mathrm{V}$, concludes the paper.

\section{LITERATURE REVIEW}

The literature has found contrasting results regarding the direction of the relationship between diversification and bank performance. For instance, Demsetz and Strahan (1997) find that diversification gains are positively related to bank asset size. Kwan (1998) has discovered that subsidiaries assuming higher risk do not guarantee greater profitability. Cornett et al. (2002) use accounting information from 40 bank holding companies in the United States with Section 20 subsidiaries. They find that these bank holding companies improve pre-tax operating cash flow returns, but no increase in risks that can be attributed to a move to investment banking activities. Smith et al. (2003) find non-interest income-based activities to be more volatile than interest-based income activities. Therefore, a negative relationship between non-interest-based income activities and interest-based income-generating activities is determined. Because of this indirect relationship, venturing into different types of activities causes a decrease in earnings volatility. In 
addition, Ramasastri et al. (2004) and Lin et al. (2005) find benefits of diversification among Indian and Taiwanese banks, respectively.

Stiroh and Rumble (2006) examine the effect of a shift toward non-interest income-based activities, such as fees-based activities and trading, on the level of performance of financial holding companies in the United States from 1997 to 2002. They find some benefits of diversification, but these are not enough to compensate for the amplified risk due to non-interest activities. The authors find that such activities are relatively more volatile but not necessarily more lucrative than interest-based activities. Their main finding shows the dark side of diversification, where its gains are not enough to offset the costs of indulging in highly volatile activities. The authors also show the implications of their findings for all the stakeholders of financial holding companies. Hirtle and Stiroh (2007) collect both accounting- and market-based data for 708 financial institutions in the United States from 1997 to 2004 to study the effects of income diversification on the risks and returns of financial institutions that concentrate on financing retail clients. The authors find that the intensity of retail banking is negatively related to market returns, especially in the case of small and medium-sized financial institutions. In the case of large financial institutions, the association between the intensity of retail banking and market returns is found to be insignificant. These large financial institutions have no effect of income diversification on earnings volatility.

Chiorazzo et al. (2008), used annual data from Italian banks and find that income diversification increases risk-adjusted returns. In their view, the comparative importance of local banks is the primary cause of the differences. The authors find that the relation between non-interest income and profitability is stronger for large banks. Their results show that smaller banks can only make profits from non-interest income if they initially have a minute share of non-interest income.

Geyfman and Yeager (2009) argue that the Gramm-Leach-Bliley Act avoided the failure of the financial markets in the United States in 2008, since independently operating investment banks were taken over by universal banks. Until now, we have reviewed the empirical literature on bank diversification that finds diversification to have benefits; on the other hand, many researchers find that it has no positive effects. For instance, DeYoung and Roland (2001) also find revenue diversification to have negative effects. To test the impact of change in the product mix of banks on earnings volatility, the authors have developed a degree of total leverage framework. Their results suggest that the move from intermediation activities toward fee-based activities is linked with not only higher revenue volatility but also greater total leverage, which, in their framework, implies higher earnings volatility. The findings of DeYoung and Roland have been verified by many others, including DeYoung and Rice (2003), Stiroh (2004, 2006b), Baele et al. (2007), Lepetit et al. (2008), Chiorazzo et al. (2008), Sanya and Wolfe (2011), and DeJonghe (2010). Others, such as Demirgüç-Kunt and Huizinga (2010), use a global sample of 1,334 banks in 101 countries leading up to the 2008 financial crisis. They find that expansion into non-interest income-based activities increases the return on assets, and, at very low levels, it can also offer risk diversification benefits. In contrast, non-deposit funding decreases the return on assets, although it can offer some level of risk reduction. Accordingly, non-interest income- or non- 
deposit funding-based banking strategies are very risky, in line with the reasons for the decline of the U.S. investment banking sector.

Abedifar et al. (2018) focus on bank size, splitting non-interest activities into different categories. They find that, generally, the lines remain non-significant in terms of banks' credit risk. Similarly, Edirisuriya et al. (2019) study the product diversification activities in a developing region, i.e., South Asia. They find securities trading positively affects bank risk, while other product categories have no impact.

Only scant literature exists on the impact of nontraditional activities on Islamic banks. Shahimi et al. (2006), using data from 1994 to 2004, examine Islamic banks in Malaysia to determine the bank characteristics that impact the enhancement of nontraditional banking activities. Their results imply that banks with higher levels of fee-generating income-based activities tend to generally have more assets and core deposits, as well as lower risk. Shahimi et al. suggest that banks that engage in nontraditional activities also have more diverse sources of funds and greater access to financial markets, which eventually reduces risk. They also note that institutions engaged in such activities tend to be safer. The authors conclude that underutilized and less utilized fee-based income activities can become an important, significant alternative source of revenue that can lessen the overdependence of Islamic banks on debt-based financing as the main source of revenue. Karakaya and Er (2013) analyze the relation between non-interest/financing income and the performance of commercial and participation banks in the Turkish banking system from 2005 to 2010. They study the impact of capital adequacy, bank size, the lending rate of financing, and general expenses, on bank risk and return performance indicators. They conclude that the variables in question have an impact on bank performance. Their empirical results show that capital adequacy, size, and credits are positively associated with bank performance, whereas general expenses are negatively associated. They also find out that non-interest income tends to increase the equity capital adequacy of understudy banks.

Molyneux and Yip (2013) have studied the linkage between income diversification and the performance of Islamic banks in six Muslim majority countries: Malaysia, Saudi Arabia, Kuwait, the United Arab Emirates, Bahrain, and Qatar. They use accounting data from 68 conventional banks and 42 Islamic banks for the period from 1997 to 2009 . They use numerous empirical approaches and find that the non-financing income of Islamic banks positively impacts their risk-adjusted performance. Greater income diversification raises volatility, which negatively affects the risk-adjusted return of banks. The authors also find Islamic banks to be less diversified compared to their conventional counterparts. Islamic banks are found to be reliant on deposit/loan financing. Since Islamic banks are not found to be involved in non-interest income-based activities, they are considered less vulnerable to earnings volatility. Molyneux and Yip also find Islamic banks to be less profitable on a risk-adjusted basis, compared to conventional banks. Ammar and Boughrara (2019) study the Middle East and North Africa region attempting to find the drivers of bank diversification decisions. They find that market share and financial intermediation play the major roles. Beside these studies on Islamic banking, the literature has generally focused on the determinants of bank risk and profitability (e.g., Bashir, 2000; Hassan and Bashir, 2003; Karim et al., 2010; 
Masruki et al., 2010; Ashraf and Rehman, 2011; Smaoui and Salah, 2011). Although some studies include non-profit income as a control variable, it has not been the subject of analysis. In this paper, we attempt to fill these gaps by studying the impact of non-intermediation activities on Indonesian banks.

\section{DATA AND METHODOLOGY}

A. Data

Our sample includes Islamic banks and conventional banks from Indonesia over the period from 2007 to 2017. This paper categorizes sample banks based on their banking model, i.e., Islamic or conventional. The data are obtained from Fitch Connect and the World Bank's World Development Indicators. For our sample, we include banks with at least three years of data. Second, we prefer unconsolidated data over consolidated data (Beck et al. (2013)), to ensure that we do not doublecount the subsidiaries of international banks. The final sample covers a total of 121 banks, of which 113 are conventional banks and eight are Islamic banks; 53 banks are considered big, equal to and over USD 1 billion in assets (Cihak and Hesse, 2010), and 68 are considered small. Given the skewness in our data set (with 113 conventional banks and eight Islamic banks), we exclude big conventional banks and re-estimate our baseline model-Equation (2) - to investigate the difference in impact for Islamic banks. Our data set is an unbalanced panel, which allows us to explore banks of different ages. This further allows us to capture bank entry into and exit from the market. Table 1 presents descriptive statistics.

\section{B. Variable definitions and empirical model}

Given the objectives of the study, the dependent variables are proxied for bank profitability and risk. Bank profitability is proxied by the return of assets $(R O A)$ and the return on equity $(R O E)$, whereas the risk is proxied by the Zscore and the standard deviation of $R O A$ (SD_ROA). For proxy of risk, we follow previous studies (Laeven and Levine, 2009; Demirgüç-Kunt and Detragiache, 2011). For the standard deviation of ROA (SD_ROA), we follow Pennathur et al. (2012), Soedarmono et al. (2013), and Noman et al., (2018), and calculate the standard deviation of ROA,SD_ROA, with a three-year rolling window (instead of the full sample period). This measure shows the number of standard deviations by which a bank's ROA must remain below its predictable value before equity is exhausted and the bank is no longer solvent. We adopt the ratio of net non-interest (financing) income to net operating income (NIIOI) as proxy for non-intermediation income, which consists of trading, fees, and commission activities. DeYoung and Roland (2001) and Stiroh and Rumble (2006) use a similar proxy and find it has a positive impact on bank profitability.

For the control variables, we propose including bank size, measured by the logarithm of total assets $(\ln T A)$; the ratio of loans to total assets $(G L T A)$; the ratio of deposits to total assets (CDTA); the ratio of equity to total assets (EQTA); and the ratio of loan/financing loss provisions to total assets (LLP). Besides these bank-specific control variables, we also incorporate macro-level control variables. Following Petria et al. (2015), we include the Herfindahl-Hirschman Index (HHI) 
in the estimations to control for market concentration. We add the gross domestic product (GDPG) and Inflation (INF) of the respective countries in our estimates. These control variables will be used to control for differences in banking structure and administrative environments. We also use some dummy variables: Islamic is a dummy representing Islamic banks. We also use the interaction dummy Islamic*NIIOI. The coefficient of Islamic*NIIOI shows if the effect of NIIOI on the dependent variable differs between Islamic and conventional banks.

This research is intended to empirically examine the relation between bank profitability or risk measures and accounting ratios by using the following dynamic panel data model:

$$
\begin{aligned}
\operatorname{Perf}_{k, t}=\alpha_{0}+\alpha_{1} \operatorname{Perf}_{k, t-1} & +\alpha_{2} \text { NIIOI }_{k, t}+\alpha_{3} \text { Control }_{k, t}+\epsilon_{k, t} \\
\operatorname{Perf}_{k, t}=\beta_{0}+\beta_{1} \operatorname{Perf}_{k, t-1} & +\beta_{2} \text { NIIOI }_{k, t}+\beta_{3}{\text { Islamic } * \text { NIIOI }_{k, t}+\beta_{4} \text { Islamic }_{k, t}}+\beta_{5} \text { Control }_{k, t}+\mu_{k, t}
\end{aligned}
$$

where for bank $k$ and time $T$, Perf refers to the return on assets (ROA), return on equity $(R O E)$, and the risk proxies, which are the Zscore and standard deviation of ROA, and NIIOI refers to non-financing income. Model (1) is modified into Model (2), where an Islamic interaction term is introduced. The variable Islamic is a dummy that takes on the value of one if the bank is Islamic, and zero otherwise. The significance of the interaction term indicates the potential difference in the relationship between non-intermediation activities and the profitability and risk for Islamic banks. Finally, Control is a list of control variables.

Following Azmi et al. (2019), we estimate the Zscore as

$$
\text { Zscore }=\frac{R O A+E / A}{\sigma R O A}
$$

where $R O A$ represents the return on assets, $E / T A$ is the equity ratio, and $\sigma R O A$ is the standard deviation of $R O A$. The Zscore represents the bank's probability of insolvency, where the higher the Zscore, the lower the bank's probability of insolvency.

\section{Methodology}

Dynamic panel data are characterized by two persistent sources over time. The first source is autocorrelation, due to the presence of a lagged dependent variable among the regressors, and the second is the specific effects characterizing heterogeneity, which could be termed the endogeneity problem. We address this problem by using the GMM procedure of Arellano and Bover (1995) and Blundell and Bond (1998). The system GMM method is much more consistent and efficient in estimating the coefficients of a model and in solving problems of endogeneity, heteroscedasticity, and autocorrelation (Arellano and Bover, 1995). The dynamic panel technique is useful in adjusting the bias due to omitted variables in cross- 
sectional estimates and endogeneity-related inconsistency. Besides that, the dynamic panel technique fits the requirements of our proposed study, where we have a relatively small number of years and a large number of cross sections per year. We check the robustness of our empirical results by repeating the same estimations using difference GMM.

\section{EMPIRICAL RESULTS}

This section presents the empirical results of our analysis. First, the descriptive statistics (Table 1) show that, on average, both big and small conventional banks in Indonesia are more profitable than Islamic banks. The variability of return is also lower for conventional banks. As far as risk is concerned, conventional banks in Indonesia are found to be more stable compared to Islamic banks. Islamic banks, on average, seem to earn more from non-intermediation activities, compared to their conventional counterparts. The variability of non-intermediation activities is similar for both types of banks.

Different diagnostic tests provide evidence of the appropriateness of the models. The number of instruments for the explanatory variables is less than the number of groups. The nonsignificance of the AR(2) test fulfills the consistency requirements of GMM estimations, in that serial autocorrelation is absent. The non-significant Hansen test results validate the instruments in the model and show that these instruments are not correlated with the error term.

\section{A. Impact of non-intermediation income on bank performance}

Table 2 shows the impact of non-intermediation income on bank performance. The results in Models (1) and (2) suggest that bank non-intermediation income has a positively significant impact of on the bank profitability proxies, $R O A$ and $R O E$. The impact of non-intermediation income on Zscore and $S D \_R O A$ is found to be nonsignificant. The impact of non-intermediation income on banks' profitability proxies and risk proxies remains unchanged, even after extra bankspecific variables are added in Models (5) to (8). This result is not in line with the studies of Stiroh et al. (2004a) or Stiroh and Rumble (2006); however, it is in line with the findings of Smith et al. (2003), Chiorazzo et al. (2008), and Molyneux and Yip (2013). Our analysis shows that, generally, income diversification increases bank profits. It is argued that the increase in bank competition results in decrease in traditional banking activities (Moshirian and Laan, 1998; Rogers and Sinkey, 1999; Allen and Santomero, 2001).

One possible explanation for positive impact of non-intermediation activities on the profitability is the advancement of technology in banking activities. Banks often provide supplementary services online. The adoption of advanced technologies has reduced bank costs. Chiorazzo et al. (2008) argue that the benefits of increased non-intermediation outweigh the disadvantages that arise from the fixed costs of technology. Given this cost-benefit tradeoff, an overall increase in non-intermediation activities enhances bank profits. Bigger banks are expected to enjoy this benefit more than smaller banks due the larger amounts of funds in hand. 


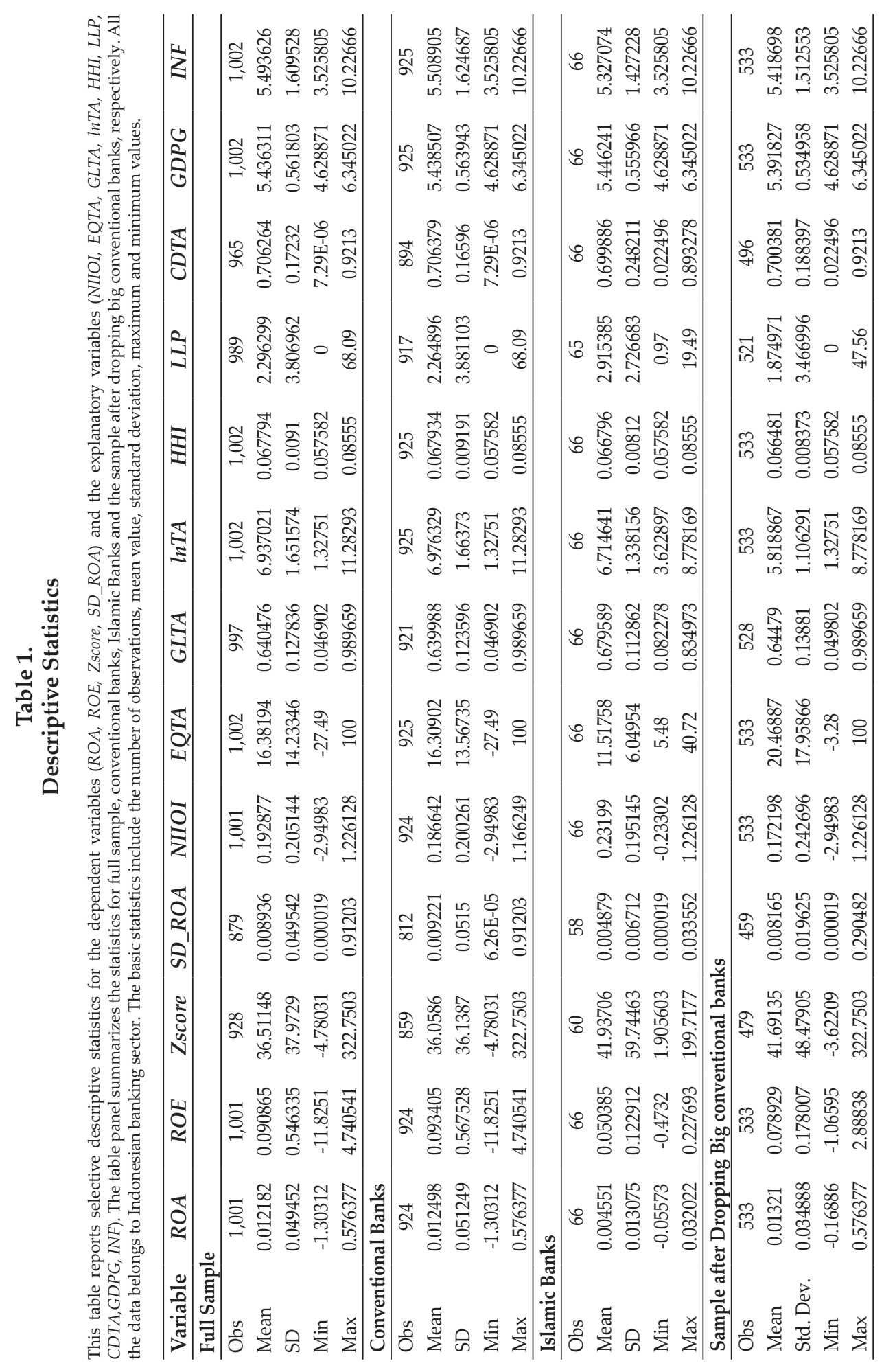


Our proxy for bank intermediation activities, GLTA, is found to be nonsignificant in all the model specifications, except Model (2). In Model (2), the positive impact of GLTA on ROE suggests that banks with larger loan ratios perform better. This could be because banks with larger loan ratios are able to accumulate higher gains (Stiroh and Rumble, 2006; Chiorazzo et al., 2008; Molyneux and Yip, 2013). Bank capitalization is found to be positive in Models (1), (3), (4), (7), and (8), suggesting that better-capitalized banks tend to perform better (Stiroh et al., 2004a). In Models (3), (4), (7), and (8), the positive impact of capitalization on the Zscore and SD_ ROA (proxies for risk performance) suggests that banks with higher capitalization have higher Zscores; however, such capitalization also increases the volatility of profitability.

Bank size proxied by the natural logarithm of total assets is found to be positive and significant in models with ROA and Zscore. This result suggests that bigger banks have higher returns on assets and are more stable. In other words, with an expansion in size, banks enjoy economies of scale and hence better performance (Beccalli et al., 2015). In Models (2) and (4), the impact of bank size has a negative relationship with $R O E$ and $S D_{-} R O A$, which could indicate the inefficient use of equity capital. The negative sign of the size variable in models with $S D_{-} R O A$ as the dependent variable suggests that bigger banks have lower volatility in their returns on assets. These findings remain consistent in the models with additional bank- specific variables, except for Model (8).

Models (1) and (2) show that GDP growth is positive and significant, suggesting that a higher GDP can result in increased profits. This could be because banks in countries with higher GDP growth tend to have better performance, due to better overall economic conditions. In Model (4), with SD_ROA, the impact of GDP growth is found to be negative, suggesting, with a higher GDP, banks tend to experience lower return volatility and, thus, lower risk. This result is in line with the findings of Stiroh et al. (2004b), Chortareas et al. (2012), and Poghosyan (2013). Inflation is found to be have a negative impact in Model (3), suggesting that banks in high-Inflation countries are more likely to have lower returns and face higher risks and are therefore exhibit less stability.

The deposit ratio and loan loss provisions are additional variables in Models (5) and (8). The deposit ratio is found to have no impact on ROA, Zscore, or SD_ $R O A$; however, the results suggest a positive impact on $R O E$. This finding suggests that banks with a higher deposit ratio have better returns on equity. One possible reason for this relationship is that banks with higher deposits are able to use these in lending and investing activities, where they can easily accumulate higher profits, resulting in less risk and greater stability. The variable $H H I$ is only significant in Model (2) and is positive. This suggests that banks in concentrated markets have higher returns on equity. Loan loss provisions are found to be significant in the case of $R O A$ and $S D_{-} R O A$, with positive and negative impacts, respectively. This result suggests that a higher $L L P$ value results in lower returns on assets and higher volatility in returns. This finding is in line with the works of DeYoung and Rice (2004a) and Chiorazzo et al. (2008). The Islamic dummy is found to be nonsignificant in terms of its impact on $R O A$ and Zscore, suggesting similarities of business structure and models. This result is in line with the literature on Islamic banks. Chong and Liu (2009) argue that Islamic banks are mimicking conventional 
banking activities and that profit and loss sharing banking activities account for only a small share of overall banking activities. In addition, they argue that profit rates in Islamic banks are attached to the rates paid by conventional banks. This finding is reaffirmed by the later studies of Khan (2010) and Molyneux et al. (2013). In Models (6) and (8), the Islamic dummy is negative, which suggests that Islamic banks have lower returns on equity and lower volatility in returns on assets.

Table 2.

\section{Impact of Non-Intermediation Income on Banks}

In this table, we report results for the impact of non-intermediation income on banks performance. In model (5-8) we have used two additional variables in the estimations i.e. Deposits ratio and loan loss provision are added. We employ System GMM to estimate the following model: $\operatorname{Perf}_{k T}=\alpha_{0}+\alpha_{1} \operatorname{Perf}_{k T-1}+\alpha_{2}$ NIIOI I $_{k T}+\alpha_{3}$ Control $_{k T}+\epsilon_{k T}$. Finally, $* * *, * *$, and ${ }^{*}$ denote statistical significance at $1 \%, 5 \%$, and $10 \%$ levels, respectively. Standard errors are reported in parentheses.

\begin{tabular}{|c|c|c|c|c|c|c|c|c|}
\hline & $\begin{array}{c}(1) \\
R O A\end{array}$ & $\begin{array}{l}(2) \\
R O E\end{array}$ & $\begin{array}{c}\text { (3) } \\
\text { Zscore }\end{array}$ & $\begin{array}{c}\text { (4) } \\
S D \_R O A\end{array}$ & $\begin{array}{c}(5) \\
R O A\end{array}$ & $\begin{array}{l}\text { (6) } \\
R O E\end{array}$ & $\begin{array}{c}(7) \\
\text { Zscore }\end{array}$ & $\begin{array}{c}\text { (8) } \\
S D \_R O A\end{array}$ \\
\hline \multirow[t]{2}{*}{$R O A(-1)$} & $0.1848^{* * * 4}$ & & & & $0.1462^{* * *}$ & & & \\
\hline & [0.053] & & & & {$[0.067]$} & & & \\
\hline \multirow[t]{2}{*}{ NIIOI } & $0.0147^{* *}$ & $0.1798^{* *}$ & -0.1581 & 0.0009 & $0.0157^{*}$ & $0.3283^{*}$ & -0.0977 & 0.0006 \\
\hline & {$[0.007]$} & {$[0.070]$} & {$[0.140]$} & [0.002] & {$[0.008]$} & [0.172] & [0.173] & [0.003] \\
\hline \multirow[t]{2}{*}{ EQTA } & $0.0004^{*}$ & -0.0022 & $0.0132^{* * *}$ & $0.0001^{* *}$ & 0.0003 & -0.0106 & $0.0246^{* * * *}$ & $0.0001^{* *}$ \\
\hline & [0.000] & {$[0.002]$} & {$[0.005]$} & {$[0.000]$} & [0.000] & [0.007] & {$[0.008]$} & {$[0.000]$} \\
\hline \multirow[t]{2}{*}{ GLTA } & -0.0044 & $1.5960^{\text {stat }}$ & -0.1197 & -0.0017 & -0.0084 & 0.5350 & -0.3695 & 0.0041 \\
\hline & {$[0.011]$} & {$[0.110]$} & {$[0.212]$} & {$[0.005]$} & {$[0.013]$} & [0.399] & [0.299] & {$[0.005]$} \\
\hline \multirow[t]{2}{*}{$\ln T A$} & $0.0019^{*+*+4}$ & $-0.0807^{* * * *}$ & $0.0469^{* * *}$ & $-0.0004^{* *}$ & $0.0029^{*+n+4}$ & 0.0705 & $0.0593^{* * *}$ & $-0.0005^{*+*+}$ \\
\hline & {$[0.001]$} & {$[0.020]$} & [0.023] & {$[0.000]$} & {$[0.001]$} & {$[0.051]$} & [0.029] & {$[0.000]$} \\
\hline \multirow[t]{2}{*}{ HHI } & -0.0101 & $6.2929^{*+4+}$ & -0.7290 & 0.0341 & -0.0202 & 5.1066 & -1.0060 & -0.0002 \\
\hline & {$[0.048]$} & [1.193] & [1.519] & [0.040] & [0.062] & [3.574] & [2.636] & [0.036] \\
\hline \multirow[t]{2}{*}{ GDPG } & $0.0028^{* *}$ & $0.0344^{*+*+}$ & -0.0117 & $-0.0014^{* * * *}$ & $0.0025^{*}$ & 0.0107 & -0.0168 & -0.0009 \\
\hline & {$[0.001]$} & {$[0.009]$} & [0.013] & {$[0.000]$} & [0.002] & [0.014] & [0.017] & [0.001] \\
\hline \multirow[t]{2}{*}{ INF } & 0.0000 & -0.0037 & $-0.0078^{*}$ & -0.0001 & 0.0003 & 0.0031 & -0.0070 & 0.0001 \\
\hline & {$[0.000]$} & [0.003] & [0.005] & {$[0.000]$} & {$[0.000]$} & {$[0.007]$} & [0.005] & [0.000] \\
\hline \multirow[t]{2}{*}{$R O E(-1)$} & & $-0.6796^{* * * x}$ & & & & $-0.5178^{* *+1+}$ & & \\
\hline & & {$[0.005]$} & & & & {$[0.029]$} & & \\
\hline \multirow[t]{2}{*}{ Zscore(-1) } & & & $0.5454^{* *+*}$ & & & & $0.5031^{* * * *}$ & \\
\hline & & & [0.105] & & & & [0.179] & \\
\hline \multirow[t]{2}{*}{$S D \_R O A(-1)$} & & & & $0.6844^{* *+*}$ & & & & $0.6926^{* * *}$ \\
\hline & & & & {$[0.001]$} & & & & {$[0.008]$} \\
\hline \multirow[t]{2}{*}{$L L P$} & & & & & $-0.0025^{* * * *}$ & -0.0038 & -0.0195 & $0.0009^{* *}$ \\
\hline & & & & & {$[0.000]$} & {$[0.005]$} & [0.019] & {$[0.000]$} \\
\hline \multirow[t]{2}{*}{ CDTA } & & & & & 0.0007 & $1.3596^{*+4}$ & 0.4786 & -0.0008 \\
\hline & & & & & [0.007] & {$[0.470]$} & [0.292] & {$[0.002]$} \\
\hline \multirow[t]{2}{*}{ Islamic } & & & & & -0.0031 & $-0.1750^{* * *}$ & -0.0817 & $-0.0011^{*}$ \\
\hline & & & & & {$[0.003]$} & {$[0.086]$} & {$[0.204]$} & {$[0.001]$} \\
\hline \multirow[t]{2}{*}{ Constant } & $-0.0239^{*}$ & $-0.8857^{* * * *}$ & $1.1853^{*+*+}$ & $0.0100^{*}$ & -0.0217 & $-1.9847^{+* *+}$ & 0.9612 & 0.0048 \\
\hline & {$[0.013]$} & {$[0.234]$} & [0.392] & [0.006] & {$[0.015]$} & {$[0.710]$} & [0.619] & {$[0.007]$} \\
\hline
\end{tabular}


Table 2.

Impact of Non-Intermediation Income on Banks (Continued)

\begin{tabular}{lcccccccc}
\hline & $\mathbf{( 1 )}$ & $\mathbf{( 2 )}$ & $\mathbf{( 3 )}$ & $\mathbf{( 4 )}$ & $\mathbf{( 5 )}$ & $\mathbf{( 6 )}$ & $\mathbf{( 7 )}$ & $\mathbf{( 8 )}$ \\
& ROA & ROE & Zscore & SD_ROA & ROA & ROE & Zscore & SD_ROA \\
\hline Observations & 874 & 874 & 794 & 753 & 843 & 843 & 769 & 728 \\
Instruments & 15.0000 & 38.0000 & 11.0000 & 10.0000 & 19.0000 & 28.0000 & 13.0000 & 14.0000 \\
Groups & 122.0000 & 122.0000 & 122.0000 & 122.0000 & 116.0000 & 116.0000 & 116.0000 & 116.0000 \\
AR(1) & 0.2667 & 0.3433 & 0.0050 & 0.2997 & 0.3630 & 0.2903 & 0.0134 & 0.2986 \\
AR(2) & 0.5475 & 0.4443 & 0.0447 & 0.0788 & 0.2742 & 0.3699 & 0.2860 & 0.3962 \\
Sargan (pv) & 0.8736 & 0.0009 & 0.2345 & 0.0404 & 0.9652 & 0.0000 & 0.1173 & 0.0000 \\
Hansen (pv) & 0.1782 & 0.1959 & 0.2324 & 0.3822 & 0.1851 & 0.3816 & 0.1703 & 0.4171 \\
\hline
\end{tabular}

\section{B. Islamic versus conventional banks}

To examine if the relationship between non-intermediation income and bank performance differs for Islamic banks in Indonesia, we modify our baseline model by introducing interaction with the Islamic dummy. The results for the modified model are presented in Table 3. We interact the Islamic dummy with non-intermediation income (Islamic ${ }^{*} \mathrm{NIIOI}$ ), to capture any potential differences in the relationship for Islamic banks.

Similar to Table 2, the results presented for Models (1) and (2) show a positive impact of non-intermediation income on $R O A$ and $R O E$, and a nonsignificant impact on Zscore and $S D \_R O A$. These results are in line with earlier findings. The non-significance of the interaction terms suggests similarity in the impact and direction of the relationship between non-intermediation income and profitability. This finding further shows that Islamic banks follow traditional banking activities and that the business structures of Islamic and conventional banks do not differ from each other.

In line with our earlier findings, capitalization is found to have positive impact on Zscore and $S D \_R O A$, where greater capitalization results in higher Zscore and higher volatility in returns on assets. Model (2) shows that capitalization negatively impacts $R O E$. This could be due to the inverse relationship between the capitalization ratio and that on the return on equity, where an increase in equity would result in increased capitalization but decreased ROE. The variable LLP is found to be consistently negative for Models (1) to (3) and positive for SD_ROA. This result suggests that an increase in $L L P$ results in lower returns, higher risks, and higher volatility in returns on assets. The deposit ratio is found to negatively impact banks' return on assets $R O A$; however, the impact of deposits on Zscore and $S D \_R O A$ shows lower risk and less volatility in returns. The variable GDPG and Inflation are found to be nonsignificant, except for Models (4) and (2), respectively. 
Table 3.

\section{Impact of Non-Intermediation Income on Banks with Interaction Terms}

In this table, we report results for the impact of non-intermediation income on banks performance with interaction terms to explore the difference in the impact for Islamic banks. These results were estimated after dropping big conventional banks from the sample. Employing System GMM estimator, Mode1s (1-4) are estimated using the following dynamic model: $\operatorname{Perf}_{k T}=\beta_{0}+\beta_{1} \operatorname{Perf}_{k T-1}+\beta_{2}$ NIIOI $_{k T}+\beta_{3}$ Islamic $* N I O I_{k T}+\beta_{4}$ Islamic $+\beta_{5} \operatorname{Control}_{k T}+\mu_{k T}$. Finally, ${ }^{* * * * *}$, and * denote statistical significance at the $1 \%, 5 \%$, and $10 \%$ levels, respectively. Standard errors are reported in parentheses.

\begin{tabular}{|c|c|c|c|c|}
\hline & $\begin{array}{c}(1) \\
R O A\end{array}$ & $\begin{array}{c}(2) \\
R O E\end{array}$ & $\begin{array}{c}\text { (3) } \\
\text { Zscore }\end{array}$ & $\begin{array}{c}\text { (4) } \\
\text { SD_ROA }\end{array}$ \\
\hline$R O A(-1)$ & $\begin{array}{l}0.1996^{* * * *} \\
{[0.004]}\end{array}$ & & & \\
\hline NIIOI & $\begin{array}{l}0.0031^{* * * *+} \\
{[0.000]}\end{array}$ & $\begin{array}{l}0.1760 * \\
{[0.095]}\end{array}$ & $\begin{array}{l}-0.0615 \\
{[0.102]}\end{array}$ & $\begin{array}{l}0.0007 \\
{[0.001]}\end{array}$ \\
\hline EQTA & $\begin{array}{l}0.0003^{* * * x} \\
{[0.000]}\end{array}$ & $\begin{array}{c}-0.0039^{* *} \\
{[0.002]}\end{array}$ & $\begin{array}{l}0.0212^{* * * *} \\
{[0.007]}\end{array}$ & $\begin{array}{l}0.0002^{* * *+} \\
{[0.000]}\end{array}$ \\
\hline GLTA & $\begin{array}{c}-0.0114^{* * *+} \\
{[0.001]}\end{array}$ & $\begin{array}{l}0.0466 \\
{[0.146]}\end{array}$ & $\begin{array}{c}-0.4622^{* *+} \\
{[0.227]}\end{array}$ & $\begin{array}{l}0.0029 \\
{[0.005]}\end{array}$ \\
\hline $\ln \mathrm{TA}$ & $\begin{array}{l}0.0045^{5 * *} \\
{[0.000]}\end{array}$ & $\begin{array}{l}-0.0243 \\
{[0.018]}\end{array}$ & $\begin{array}{l}0.0324 \\
{[0.039]}\end{array}$ & $\begin{array}{l}-0.0001 \\
{[0.000]}\end{array}$ \\
\hline HHI & $\begin{array}{l}0.5356^{* * *} \\
{[0.020]}\end{array}$ & $\begin{array}{l}1.8614 \\
{[1.348]}\end{array}$ & $\begin{array}{l}-2.4056 \\
{[2.172]}\end{array}$ & $\begin{array}{l}-0.0078 \\
{[0.041]}\end{array}$ \\
\hline GDPG & $\begin{array}{l}0.0017^{* n * x} \\
{[0.000]}\end{array}$ & $\begin{array}{l}-0.0021 \\
{[0.012]}\end{array}$ & $\begin{array}{l}-0.0239 \\
{[0.019]}\end{array}$ & $\begin{array}{c}-0.0011^{* * * *} \\
{[0.000]}\end{array}$ \\
\hline INF & $\begin{array}{l}0.0010^{+3 x+*} \\
{[0.000]}\end{array}$ & $\begin{array}{l}-0.0038^{*} \\
{[0.002]}\end{array}$ & $\begin{array}{l}0.0030 \\
{[0.005]}\end{array}$ & $\begin{array}{l}0.0002 \\
{[0.000]}\end{array}$ \\
\hline LLP & $\begin{array}{c}-0.0028^{* *+*} \\
{[0.000]}\end{array}$ & $\begin{array}{c}-0.0059^{* *+} \\
{[0.002]}\end{array}$ & $\begin{array}{c}-0.0375^{* *} \\
{[0.019]}\end{array}$ & $\begin{array}{l}0.0014^{*+*+} \\
{[0.000]}\end{array}$ \\
\hline CDTA & $\begin{array}{l}-0.0017^{*} \\
{[0.001]}\end{array}$ & $\begin{array}{l}-0.0668 \\
{[0.136]}\end{array}$ & $\begin{array}{l}0.9368^{* * * x} \\
{[0.291]}\end{array}$ & $\begin{array}{c}-0.0030^{* * * x} \\
{[0.001]}\end{array}$ \\
\hline Islamic & $\begin{array}{c}-0.0044^{* * *+} \\
{[0.001]}\end{array}$ & $\begin{array}{l}-0.0081 \\
{[0.042]}\end{array}$ & $\begin{array}{l}-0.0419 \\
{[0.184]}\end{array}$ & $\begin{array}{c}-0.0020^{* *} \\
{[0.001]}\end{array}$ \\
\hline Islamic ${ }^{*} \mathrm{NIIOI}$ & $\begin{array}{l}0.0024 \\
{[0.002]}\end{array}$ & $\begin{array}{l}-0.1658 \\
{[0.106]}\end{array}$ & $\begin{array}{l}0.0912 \\
{[0.226]}\end{array}$ & $\begin{array}{l}0.0022 \\
{[0.003]}\end{array}$ \\
\hline ROE(-1) & & $\begin{array}{l}0.3526^{* * * x} \\
{[0.112]}\end{array}$ & & \\
\hline Zscore(-1) & & & $\begin{array}{l}0.5695^{* * *} \\
{[0.146]}\end{array}$ & \\
\hline$S D \_R O A(-1)$ & & & & $\begin{array}{l}0.6248^{*+*} \\
{[0.031]}\end{array}$ \\
\hline Constant & $\begin{array}{c}-0.0606^{*+*} \\
{[0.001]} \\
\end{array}$ & $\begin{array}{l}0.1806 \\
{[0.247]}\end{array}$ & $\begin{array}{l}0.8264^{*} \\
{[0.459]}\end{array}$ & $\begin{array}{l}0.0040 \\
{[0.005]}\end{array}$ \\
\hline Observations & 426 & 426 & 377 & 359 \\
\hline instruments & 55.0000 & 21.0000 & 21.0000 & 20.0000 \\
\hline groups & 67.0000 & 67.0000 & 67.0000 & 67.0000 \\
\hline $\mathrm{AR}(1)$ & 0.0236 & 0.3588 & 0.0918 & 0.0460 \\
\hline $\mathrm{AR}(2)$ & 0.7822 & 0.7420 & 0.4799 & 0.4865 \\
\hline Sargan (pv) & 0.0000 & 0.6536 & 0.3747 & 0.0500 \\
\hline Hansen (pv) & 0.2648 & 0.1076 & 0.5933 & 0.7310 \\
\hline
\end{tabular}




\section{Big versus Small Banks}

In further analysis, we split the sample into big and small banks and re-estimate the modified baseline model. Banks with total assets of equal to and more than USD 1 billion (Big) are categorized as big banks, while banks with total assets of less than USD 1 billion (Small) are considered small. The sample thus can be split into 53 big banks and 68 small banks.

Table 4 presents the results for the subsamples of big and small banks, using system GMM. Models (1) to (4) show the impact of non-intermediation income on performance for big banks and Models (5) to (8) show the results for small banks.

For big banks, the impact of non-intermediation income on $R O A, R O E$, and $S D \_R O A$ is positive, and it is insignificant for Zscore. The results indicate that, for big banks, an increase in non-Intermediation income results in higher returns on assets and on equity. The results further suggest that greater non-intermediation income could induce higher volatility to $R O A$ (positive sign for $S D \_R O A$ ). For smaller banks, the results show no difference in the impact on ROA and Zscore, the same as for big banks. Interestingly, the impact of non-intermediation income on $R O E$ is found to be negative (Model (6)), suggesting that greater non-intermediation income could lead to lower returns on equity in small banks. This result adds value to our earlier findings and suggests that non-intermediation income explains a significant share of bank performance. Intermediation through lending channels is found to only impact the Zscore negatively in small banks. However, bigger banks with larger loans are able to accumulate higher gains on assets. This result suggests that small banks with higher levels of lending are likely to engage in risky investments. The interaction terms are found to be mostly nonsignificant. In big banks, the interaction term is negative and significant in Model (2), suggesting that bigger Islamic banks have a negative impact on $R O E$, unlike bigger conventional banks. For small banks, the interaction term is found to be negative and significant for Model (5), which suggests that in small Islamic banks, the non-intermediation income have a negative impact on $R O A$, unlike small conventional banks.

\section{Table 4.}

\section{Impact of Non-Intermediation Income on Big and Small Banks}

In this table, we report results for the impact of non-intermediation income on banks performance with interaction terms to explore the difference in the impact for Islamic banks after splitting the sample into Big and Small banks. Employing System GMM, Mode1 (1-4) are estimated using the following model: $\operatorname{Perf}_{k T}=\beta_{0}+\beta_{1} \operatorname{Perf}_{k T-1}+\beta_{2}$ NIIOI $_{k T}+\beta_{3}$ Islamic $* N I I O I_{k T}+\beta_{4}$ Islamic $+\beta_{5}$ Control $_{k T}+\mu_{k T}$. Finally, ${ }^{* * * * * * *}$, and

* denote statistical significance at the $1 \%, 5 \%$, and $10 \%$ levels, respectively. Standard errors are reported in parentheses.

\begin{tabular}{lcccccccc}
\hline & \multicolumn{4}{c}{ Big Banks } & \multicolumn{5}{c}{ Small Banks } \\
\cline { 2 - 9 } & ROA & ROE & Zscore & SD_ROA & ROA & ROE & Zscore & SD_ROA \\
\hline ROA(-1) & $0.2565^{* * *}$ & & & & 0.4198 & & & \\
\multirow{3}{*}{ NIIOI } & {$[0.048]$} & & & & {$[0.359]$} & & & \\
& $0.0114^{*}$ & $0.9526^{* * *}$ & 0.0685 & $0.0419^{* * *}$ & $0.0916^{* * *}$ & $-0.1858^{*}$ & -0.057 & -0.0024 \\
\multirow{3}{*}{ EQTA } & {$[0.007]$} & {$[0.110]$} & {$[0.210]$} & {$[0.003]$} & {$[0.015]$} & {$[0.105]$} & {$[0.048]$} & {$[0.007]$} \\
& $0.0015^{* * *}$ & $-0.0105^{* * *}$ & $0.0214^{* *}$ & $-0.0006^{* *}$ & 0.0014 & $-0.0045^{* *}$ & $0.0136^{* * *}$ & 0.0001 \\
\multirow{3}{*}{ GLTA } & {$[0.000]$} & {$[0.004]$} & {$[0.011]$} & {$[0.000]$} & {$[0.001]$} & {$[0.002]$} & {$[0.005]$} & {$[0.000]$} \\
& $0.0328^{* *}$ & -0.2036 & -0.1622 & -0.006 & -0.0503 & 0.0578 & $-0.4125^{*}$ & 0.0163 \\
& {$[0.015]$} & {$[0.172]$} & {$[0.155]$} & {$[0.016]$} & {$[0.046]$} & {$[0.095]$} & {$[0.250]$} & {$[0.012]$} \\
\hline
\end{tabular}


Table 4.

Impact of Non-Intermediation Income on Big and Small Banks (Continued)

\begin{tabular}{|c|c|c|c|c|c|c|c|c|}
\hline & \multicolumn{4}{|c|}{ Big Banks } & \multicolumn{4}{|c|}{ Small Banks } \\
\hline & $R O A$ & $R O E$ & Zscore & $S D \_R O A$ & $R O A$ & $R O E$ & Zscore & $S D \_R O A$ \\
\hline \multirow[t]{2}{*}{$\ln T A$} & $0.0069^{* *+4}$ & $0.1931^{* *+4}$ & 0.0222 & $-0.0042^{* * * *}$ & 0.0054 & 0.01 & $0.0563^{* * *}$ & 0.0018 \\
\hline & {$[0.001]$} & {$[0.037]$} & [0.023] & {$[0.001]$} & {$[0.005]$} & [0.015] & {$[0.025]$} & [0.002] \\
\hline \multirow[t]{2}{*}{ HHI } & $2.7464^{*+* x}$ & $4.6327^{* * *}$ & 1.5556 & $-0.8612^{* *+}$ & 1.4105 & $2.4172^{* * *}$ & 2.7312 & $1.0966^{* *}$ \\
\hline & {$[0.154]$} & [1.833] & [1.171] & {$[0.343]$} & [1.455] & [1.114] & [4.406] & [0.447] \\
\hline \multirow[t]{2}{*}{ GDPG } & $-0.0072^{* * *+}$ & $0.0249^{*}$ & 0.013 & $0.0061^{* * * *}$ & -0.0066 & -0.0026 & $-0.0513^{* * *}$ & -0.0055 \\
\hline & {$[0.002]$} & {$[0.014]$} & {$[0.018]$} & {$[0.001]$} & {$[0.006]$} & [0.009] & {$[0.023]$} & [0.004] \\
\hline \multirow[t]{2}{*}{ INF } & $-0.0011^{*+*+}$ & $0.0092^{*+*+}$ & $-0.0128^{* *}$ & $-0.0014^{*}$ & -0.001 & 0.0039 & $0.0152^{* * *}$ & $0.0020^{* * *}$ \\
\hline & {$[0.000]$} & {$[0.003]$} & {$[0.005]$} & {$[0.001]$} & {$[0.002]$} & [0.003] & {$[0.007]$} & {$[0.001]$} \\
\hline \multirow[t]{2}{*}{ LLP } & $-0.0010^{*+4+4}$ & $-0.0049^{*}$ & 0.0035 & $0.0047^{+* * x}$ & $-0.0020^{* * *}$ & -0.0021 & -0.0048 & $0.0029^{* * *}$ \\
\hline & {$[0.000]$} & {$[0.003]$} & [0.009] & {$[0.000]$} & {$[0.001]$} & {$[0.002]$} & {$[0.010]$} & {$[0.001]$} \\
\hline \multirow[t]{2}{*}{ CDTA } & $-0.0386^{*+1}$ & $0.2118^{*}$ & 0.0309 & $0.0186^{*+*}$ & 0.0117 & $-0.2401^{* * *}$ & $0.4993^{* * x}$ & $-0.0145^{*+*}$ \\
\hline & {$[0.010]$} & [0.122] & {$[0.084]$} & {$[0.004]$} & {$[0.028]$} & [0.102] & [0.189] & {$[0.005]$} \\
\hline \multirow[t]{2}{*}{ Islamic } & 0.1127 & $0.2602^{*}$ & 0.1037 & -0.0017 & $0.0238^{* *}$ & $-0.1510^{n+*}$ & -0.0513 & -0.0075 \\
\hline & {$[0.088]$} & {$[0.148]$} & [0.103] & [0.005] & {$[0.012]$} & {$[0.042]$} & [0.132] & {$[0.006]$} \\
\hline \multirow[t]{2}{*}{ Islamic*NIIOI } & -0.4392 & $-0.9048^{*}$ & -0.0811 & -0.0301 & $-0.0960^{* * *}$ & 0.2842 & 0.0662 & 0.0147 \\
\hline & {$[0.367]$} & {$[0.465]$} & {$[0.310]$} & {$[0.027]$} & {$[0.044]$} & [0.175] & {$[0.209]$} & {$[0.013]$} \\
\hline \multirow[t]{2}{*}{$R O E(-1)$} & & $-0.6784^{* *+4}$ & & & & $0.3609^{* * * * *}$ & & \\
\hline & & {$[0.004]$} & & & & {$[0.025]$} & & \\
\hline \multirow[t]{2}{*}{ Zscore(-1) } & & & $0.9208^{* * *+}$ & & & & $0.7951^{* * *+}$ & \\
\hline & & & [0.137] & & & & {$[0.115]$} & \\
\hline \multirow[t]{2}{*}{$S D \_R O A(-1)$} & & & & $-0.0113^{* * * *}$ & & & & 0.0322 \\
\hline & & & & {$[0.004]$} & & & & {$[0.040]$} \\
\hline \multirow[t]{2}{*}{ Constant } & $-0.2006^{* *+}$ & $-2.0377^{*+1+4}$ & -0.2314 & 0.0492 & -0.0893 & 0.0788 & 0.0539 & $-0.0636^{* * *}$ \\
\hline & {$[0.027]$} & {$[0.391]$} & {$[0.300]$} & {$[0.031]$} & [0.107] & [0.153] & [0.477] & {$[0.031]$} \\
\hline Observations & 454 & 454 & 433 & 411 & 389 & 389 & 336 & 317 \\
\hline instruments & 18.0000 & 33.0000 & 20.0000 & 18.0000 & 20.0000 & 21.0000 & 20.0000 & 18.0000 \\
\hline Groups & 65.0000 & 65.0000 & 65.0000 & 65.0000 & 74.0000 & 74.0000 & 72.0000 & 71.0000 \\
\hline $\operatorname{AR}(1)$ & 0.3367 & 0.4470 & 0.0014 & 0.2626 & 0.0669 & 0.1721 & 0.0369 & 0.3052 \\
\hline $\operatorname{AR}(2)$ & 0.0835 & 0.3195 & 0.1820 & 0.4220 & 0.2262 & 0.3925 & 0.0651 & 0.3267 \\
\hline Sargan (pv) & 0.2079 & 0.0000 & 0.4349 & 0.9631 & 0.9904 & 0.1780 & 0.1871 & 0.9940 \\
\hline Hansen (pv) & 0.6821 & 0.0180 & 0.1950 & 0.0157 & 0.4988 & 0.3485 & 0.2554 & 0.2731 \\
\hline
\end{tabular}

\section{Robustness}

To add robustness to our findings, we re-estimate the models with difference GMM and random effects estimators. The results are shown in Table 5. With difference GMM estimator the main results are found to be in line with our earlier findings. The impact of non-intermediation income on $R O A$ and $R O E$ remains positive, suggesting that income diversification enhances bank performance. The impact on Zscore, however, is found to be nonsignificant, also consistent with our earlier results. Surprisingly, the impact of non-intermediation income on $R O E$ is found to be negative, and the impact on Zscore becomes positive when estimated with random effects estimator. Most of the control variables are in line with earlier 
findings. The difference in the relationships of the different control variables can be explained by changes in estimation technique, which is not our focus here. The interaction term is found to be positive only for Zscore when calculated with random effects estimator (Model (7)). The nonsignificance of interaction terms in most of the regression models demonstrates the robustness of our earlier results, suggesting no difference in the relationships between Islamic and conventional banks.

Table 5.

\section{Impact of Non-Intermediation Income on Banks Using Difference GMM and Random Effect}

In this table, we report results the robustness checks for the results on the impact of non-intermediation income on banks performance with interaction terms to explore the difference in the impact for Islamic banks. These results were estimated after dropping big conventional banks from the sample. Employing Difference GMM estimator and Random effects estimator, Model (1-4) and Model (5-8) are estimated using the following dynamic model: $\operatorname{Perf}_{k T}=\beta_{0}+\beta_{1} \operatorname{Perf}_{k T-1}+\beta_{2}$ NIIOI $_{k T}+\beta_{3}$ Islamic $* N I I O I_{k T}+\beta_{4}$ Islamic $+\beta_{5}$ Control $_{k T}+\mu_{k T}$, respectively. Finally, $* * * * *$, and ${ }^{*}$ denote statistical significance at the $1 \%, 5 \%$, and $10 \%$ levels, respectively. Standard errors are reported in parentheses.

\begin{tabular}{|c|c|c|c|c|c|c|c|c|}
\hline & $\begin{array}{c}(1) \\
R O A\end{array}$ & $\begin{array}{c}(2) \\
R O E\end{array}$ & $\begin{array}{c}\text { (3) } \\
\text { Zscore }\end{array}$ & $\begin{array}{c}\text { (4) } \\
S D \_R O A\end{array}$ & $\begin{array}{c}\text { (5) } \\
R O A\end{array}$ & $\begin{array}{c}\text { (6) } \\
R O E\end{array}$ & $\begin{array}{c}\text { (7) } \\
\text { Zscore }\end{array}$ & $\begin{array}{c}\mathbf{( 8 )} \\
S D \_R O A\end{array}$ \\
\hline$R O A(-1)$ & $\begin{array}{c}-0.2158^{* * *+} \\
{[0.022]}\end{array}$ & & & & & & & \\
\hline NIIOI & $\begin{array}{l}0.1687^{\prime *} \\
{[0.070]}\end{array}$ & $\begin{array}{l}0.2200^{*} \\
{[0.119]}\end{array}$ & $\begin{array}{l}0.4278 \\
{[0.265]}\end{array}$ & $\begin{array}{l}0.0069 \\
{[0.009]}\end{array}$ & $\begin{array}{l}0.0377^{* * * *} \\
{[0.009]}\end{array}$ & $\begin{array}{c}-0.3856^{* * 4+4} \\
{[0.122]}\end{array}$ & $\begin{array}{l}0.0860^{*} \\
{[0.044]}\end{array}$ & $\begin{array}{l}-0.0143 \\
{[0.010]}\end{array}$ \\
\hline$E Q T A$ & $\begin{array}{l}0.0005 \\
{[0.001]}\end{array}$ & $\begin{array}{l}-0.0066 \\
{[0.005]}\end{array}$ & $\begin{array}{l}0.0537^{* 3 *} \\
{[0.006]}\end{array}$ & $\begin{array}{l}0.0011^{* *} \\
{[0.000]}\end{array}$ & $\begin{array}{l}0.0012^{* * *+4} \\
{[0.000]}\end{array}$ & $\begin{array}{l}-0.0028 \\
{[0.003]}\end{array}$ & $\begin{array}{l}0.0484^{* * *} \\
{[0.005]}\end{array}$ & $\begin{array}{c}-0.0010^{* *+*} \\
{[0.000]}\end{array}$ \\
\hline GLTA & $\begin{array}{l}-0.0192 \\
{[0.052]}\end{array}$ & $\begin{array}{l}-0.0830 \\
{[0.261]}\end{array}$ & $\begin{array}{l}-0.0913 \\
{[0.221]}\end{array}$ & $\begin{array}{l}0.0324 \\
{[0.031]}\end{array}$ & $\begin{array}{c}-0.0302^{* *} \\
{[0.013]}\end{array}$ & $\begin{array}{l}0.1612 \\
{[0.202]}\end{array}$ & $\begin{array}{l}0.1059 \\
{[0.136]}\end{array}$ & $\begin{array}{l}0.0311^{*} \\
{[0.016]}\end{array}$ \\
\hline $\ln T A$ & $\begin{array}{l}0.0146 \\
{[0.013]}\end{array}$ & $\begin{array}{l}0.0205 \\
{[0.051]}\end{array}$ & $\begin{array}{l}0.0315 \\
{[0.052]}\end{array}$ & $\begin{array}{l}0.0329^{* *} \\
{[0.013]}\end{array}$ & $\begin{array}{l}0.0052^{\text {Now }} \\
{[0.001]}\end{array}$ & $\begin{array}{l}0.0176 \\
{[0.019]}\end{array}$ & $\begin{array}{l}0.0100 \\
{[0.036}\end{array}$ & $\begin{array}{c}-0.0039^{* * *+*} \\
{[0.001]}\end{array}$ \\
\hline HHI & $\begin{array}{l}0.5301 \\
{[0.446]}\end{array}$ & $\begin{array}{l}0.7867 \\
{[2.698]}\end{array}$ & $\begin{array}{l}-0.3466 \\
{[2.593]}\end{array}$ & $\begin{array}{l}2.7987^{* *} \\
{[1.103]}\end{array}$ & $\begin{array}{l}-0.0643 \\
{[0.175]}\end{array}$ & $\begin{array}{l}4.0700^{*} \\
{[2.331]}\end{array}$ & $\begin{array}{l}-1.9467 \\
{[1.942]}\end{array}$ & $\begin{array}{l}0.3217 \\
{[0.196]}\end{array}$ \\
\hline GDPG & $\begin{array}{l}0.0008 \\
{[0.003]}\end{array}$ & $\begin{array}{l}0.0467^{* 3 \times} \\
{[0.011]}\end{array}$ & $\begin{array}{l}0.0190 \\
{[0.012]}\end{array}$ & $\begin{array}{l}-0.0028 \\
{[0.002]}\end{array}$ & $\begin{array}{l}0.0020 \\
{[0.003]}\end{array}$ & $\begin{array}{l}0.0263 \\
{[0.035]}\end{array}$ & $\begin{array}{l}0.0186^{*} \\
{[0.011]}\end{array}$ & $\begin{array}{l}-0.0003 \\
{[0.003]}\end{array}$ \\
\hline INF & $\begin{array}{l}0.0009 \\
{[0.001]}\end{array}$ & $\begin{array}{l}0.0177^{1} \\
{[0.007]}\end{array}$ & $\begin{array}{l}-0.0032 \\
{[0.004]}\end{array}$ & $\begin{array}{l}0.0085^{+3+4} \\
{[0.003]}\end{array}$ & $\begin{array}{l}-0.0014 \\
{[0.001]}\end{array}$ & $\begin{array}{l}0.0062 \\
{[0.011]}\end{array}$ & $\begin{array}{l}-0.0060^{*+*} \\
{[0.003]}\end{array}$ & $\begin{array}{l}0.0002 \\
{[0.001]}\end{array}$ \\
\hline LLP & $\begin{array}{c}-0.0090^{* * * *} \\
{[0.001]}\end{array}$ & $\begin{array}{l}0.0049 \\
{[0.020]}\end{array}$ & $\begin{array}{l}-0.0083 \\
{[0.006]}\end{array}$ & $\begin{array}{l}0.0038^{*+*} \\
{[0.000]}\end{array}$ & $\begin{array}{c}-0.0038^{* *+4} \\
{[0.000]}\end{array}$ & $\begin{array}{l}0.0070 \\
{[0.005]}\end{array}$ & $\begin{array}{l}0.0004 \\
{[0.004]}\end{array}$ & $\begin{array}{l}0.0051^{\text {wat }} \\
{[0.000]}\end{array}$ \\
\hline CDTA & $\begin{array}{l}-0.0387 \\
{[0.068]}\end{array}$ & $\begin{array}{l}-0.1539 \\
{[0.254]}\end{array}$ & $\begin{array}{l}-0.3179 \\
{[0.376]}\end{array}$ & $\begin{array}{l}-0.0312^{*} \\
{[0.016]}\end{array}$ & $\begin{array}{l}0.0124 \\
{[0.010]}\end{array}$ & $\begin{array}{l}0.1024 \\
{[0.152]}\end{array}$ & $\begin{array}{l}-0.1393^{*} \\
{[0.076]}\end{array}$ & $\begin{array}{l}-0.0105 \\
{[0.012]}\end{array}$ \\
\hline Islamic & $\begin{array}{c}0.0000 \\
{[.]}\end{array}$ & $\begin{array}{c}0.0000 \\
{[.]}\end{array}$ & $\begin{array}{c}0.0000 \\
{[.]}\end{array}$ & $\begin{array}{c}0.0000 \\
{[.]}\end{array}$ & $\begin{array}{l}0.0097 \\
{[0.009]}\end{array}$ & $\begin{array}{l}-0.1580 \\
{[0.139]}\end{array}$ & $\begin{array}{l}-0.1978 \\
{[0.458]}\end{array}$ & $\begin{array}{l}-0.0203^{*} \\
{[0.010]}\end{array}$ \\
\hline 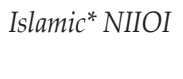 & $\begin{array}{l}-0.2209 \\
{[0.305]}\end{array}$ & $\begin{array}{l}0.1128 \\
{[0.239]}\end{array}$ & $\begin{array}{l}-3.9419 \\
{[3.404]}\end{array}$ & $\begin{array}{l}-0.0127 \\
{[0.024]}\end{array}$ & $\begin{array}{l}-0.0371 \\
{[0.028]}\end{array}$ & $\begin{array}{l}0.5706 \\
{[0.377]}\end{array}$ & $\begin{array}{l}0.2218^{* *} \\
{[0.105]}\end{array}$ & $\begin{array}{l}0.0373 \\
{[0.029]}\end{array}$ \\
\hline$R O E(-1)$ & & $\begin{array}{c}-1.3624^{*+*+1} \\
{[0.061]}\end{array}$ & & & & & & \\
\hline Zscore(-1) & & & $\begin{array}{l}-0.0791 \\
{[0.113]}\end{array}$ & & & & & \\
\hline$S D_{-} R O A(-1)$ & & & & $\begin{array}{l}0.0266 \\
{[0.037]}\end{array}$ & & & & \\
\hline Constant & & & & & $\begin{array}{l}-0.0299 \\
{[0.021]} \\
\end{array}$ & $\begin{array}{c}-0.5678^{*} \\
{[0.327]} \\
\end{array}$ & $\begin{array}{c}2.5390^{* * *} \\
{[0.506]}\end{array}$ & $\begin{array}{l}0.0078 \\
{[0.025]}\end{array}$ \\
\hline
\end{tabular}


Table 5.

Impact of Non-Intermediation Income on Banks Using Difference GMM and Random Effect (Continued)

\begin{tabular}{lcccccccc}
\hline & $\mathbf{( 1 )}$ & $\mathbf{( 2 )}$ & $\mathbf{( 3 )}$ & $\mathbf{( 4 )}$ & $\mathbf{( 5 )}$ & $\mathbf{( 6 )}$ & $\mathbf{( 7 )}$ & $\mathbf{( 8 )}$ \\
& ROA & ROE & Zscore & SD_ROA & ROA & ROE & Zscore & SD_ROA \\
\hline & D-GMM & D-GMM & D-GMM & D-GMM & RE & RE & RE & RE \\
\hline Observations & 727 & 727 & 653 & 612 & 958 & 958 & 892 & 844 \\
Instruments & 23.0000 & 13.0000 & 16.0000 & 15.0000 & & & & \\
Groups & 116.0000 & 116.0000 & 115.0000 & 114.0000 & 116.0000 & 116.0000 & 116.0000 & 116.0000 \\
AR(1) & 0.9966 & 0.4258 & 0.1731 & 0.1843 & & & & \\
AR(2) & 0.4189 & 0.0603 & 0.3789 & 0.1622 & & & & \\
Sargan (pv) & 0.0000 & 0.0000 & 0.9021 & 0.9284 & & & & \\
Hansen (pv) & 0.8436 & 0.0318 & 0.7166 & 0.0767 & & & & \\
\hline
\end{tabular}

\section{CONCLUSION}

The main objective of our research is to investigate the impact of non-intermediation income on bank performance in the Indonesian banking sector. We apply system GMM to a sample of 121 banks for the period 2007-2017. Our main results suggest that non-intermediation income has positive impact on bank performance. This indicates that banks with greater income diversification tend to perform better. Moreover, we find that non-intermediation activities increase returns on assets, regardless of bank size. However, the impact of non-intermediation income differs for returns on equity between big and small banks. Big banks appear to enjoy higher returns on equity with an increase in non-intermediation income, but the latter leads to lower returns on equity. We further look for potential differences in the relationships between Islamic and conventional banks. No difference is found in the relationship between non-intermediation income and bank performance.

These results have policy implications for the regulators and practitioners. One of the most important is that income diversification can lead to higher gains and better performance. Second, Islamic banks' activities are similar to those of conventional banks. Given the country's large population, Islamic banks in Indonesia can benefit more through diversifying their investments in profit and loss sharing-based investments, which is the true essence of Islamic banking and appreciated much more under Shari'ah.

As far as the study's limitations are concerned, we were dependent on the data provided by Fitch, which does not provide data for the entire banking sector. The availability of better data could have made this study more robust. Additionally, we recommend a more complete data set in future studies. To obtain more objective policy directions, we also recommend studying the impact of individual components of bank non-intermediation activities on bank performance. 


\section{REFERENCES}

Abedifar, P., Molyneux, P., \& Tarazi, A. (2013). Risk in Islamic Banking. Review of Finance, 17, 2035-2096.

Abedifar, P., Molyneux, P., \& Tarazi, A. (2018). Non-Interest Income and Bank Lending. Journal of Banking and Finance, 87, 411-426.

Allen, F. \& Santomero, A.M. (2001). What Do Financial Intermediaries Do? Journal of Banking and Finance, 25, 271-294.

Ammar, N., \& Boughrara, A. (2019). What Drives the Banks' Diversification Decision? A Dynamic Nonlinear Panel Data Approach. Managerial and Decision Economics, 40, 907-922.

Arellano, M., \& Bover, O. (1995). Another Look at The Instrumental Variable's Estimation of Error-Component Models. Journal of Econometrics, 68, 29-51.

Ashraf, M. M., \& Rehman, Z. (2011). The Performance Analysis of Islamic and Conventional Banks: The Pakistan's Perspective. Journal of Money, Investment and Banking, 22, 99-113.

Azmi, W., Ali, M., Arshad, S., \& Rizvi, S. A. R. (2019). Intricacies of Competition, Stability, and Diversification: Evidence from Dual Banking Economies. Economic Modelling, 83, 111-126.

Baele, L., De Jonghe, O., Vander Vennet, R., (2007). Does The Stock Market Value Bank Diversification? Journal of Banking and Finance, 31, 1999-2023.

Bashir, A. M. (2000). Determinants of Profitability and Rate of Return Margins in Islamic Banks: Some Evidence from The Middle East. ERF's Seventh Annual Conference.

Beccalli, E., Anolli, M., \& Borello, G. (2015). Are European Banks Too Big? Evidence on Economies of Scale. Journal of Banking and Finance, 58, 232-246.

Beck, T., Demirgüç-Kunt, A., \& Merrouche, O. (2013). Islamic vs. Conventional Banking: Business Model, Efficiency and Stability. Journal of Banking and Finance, 37, 433- 447.

Bertocco, G., (2008). Finance and Development: Is Schumpeter's Analysis Still Relevant? Journal of Banking and Finance, 32, 1161-1175.

Blundell, R., \& Bond, S. (1998). GMM Estimation with Persistent Panel Data: An Application to Production Functions, Working Paper, IFS No. W99/04.

Chiorazzo, V., Milani, C., \& Salvini, F. (2008). Income Diversification and Bank Performance: Evidence from Italian Banks. Journal of Financial Services Research, 33, 181-203.

Chong, B. S., \& Liu, M. H. (2009). Islamic Banking: Interest-Free or Interest-Based? Pacific-Basin Finance Journal, 17, 125-144.

Chortareas, G. E., Girardone, C., \& Ventouri, A. (2012). Bank Supervision, Regulation, and Efficiency: Evidence from The European Union. Journal of Financial Stability, 8, 292-302.

Čihák, M., \& Hesse, H. (2010). Islamic Banks and Financial Stability: An Empirical Analysis. Journal of Financial Services Research, 38, 95-113.

Cornett, M.M., Ors E., \& Tehranian, H. (2002). Bank Performance Around the Introduction of a Section 20 Subsidiary. Journal of Finance, 57, 501-521.

De Jonghe, O. (2010). Back to the Basics in Banking? A Micro-Analysis of Banking System Stability. Journal of Financial Intermediation, 19, 387-417. 
Deesomsak, R., Paudyal, K., \& Pescetto, G. (2004). The Determinants of Capital Structure: Evidence from The Asia Pacific Region. Journal of Multinational Management, 14, 387-405.

Demirgüc-Kunt, A., \& Huizinga, H., (2010). Bank Activity and Funding Strategies: The Impact on Risk and Returns. Journal of Financial Economics, 98, 626-650.

Demirgüç-Kunt, A., and Detragiache, E. (2011). Basel Core Principles and Bank Soundness: Does Compliance Matter? Journal of Financial Stability, 7, 179-190.

Demsetz, R.S., \& Strahan, P.E., (1997). Diversification, Size, And Risk at Bank Holding Companies. Journal of Money, Credit and Banking, 29, 300-313.

DeYoung, R., \& Rice, T. (2003). Non-Interest Income and Financial Performance at US Commercial Banks, Federal Reserve Bank of Chicago, August 2003, S\&R2003-2.

DeYoung, R., \& Rice, T. (2004). Noninterest Income and Financial Performance at US Commercial Banks. Financial Review, 39, 101-127.

DeYoung, R., \& Roland, K. P. (2001). Product Mix and Earnings Volatility at Commercial Banks: Evidence from A Degree of Total Leverage Model. Journal of Financial Intermediation, 10, 54-84.

Edirisuriya P., Gunasekarage, A., \& Perera S. (2019) Product Diversification and Bank Risk: Evidence from South Asian Banking Institutions, Applied Economics, 51, 444-464

Fauver, L., Houston, J., \& Naranjo, A. (2003). Capital Market Development, International Integration, Legal Systems, and the Value of Corporate Diversification: A Cross-Country Analysis. Journal of Financial and Quantitative Analysis, 38, 135-158.

Geyfman, V., \& Yeager ,T.J. (2009). On the Riskiness of Universal Banking: Evidence from Banks in the Investment Banking Business Pre- and Post-GLBA. Journal of Money, Credit and Banking, 41, 1649-1669.

Haron, S., \& Azmi, W. N. (2004). Profitability Determinants of Islamic Banks. Islamic Banking Conference, Union Arab Bank, Beirut, Lebanon.

Hassan, M. K., \& Bashir, A. M. (2003). Determinants of Islamic Banking Profitability. In 10th ERF annual conference, Morocco, 7, 2-31.

Hirtle, B. J., \& Stiroh, K. J. (2007). The Return to Retail and the Performance of US Banks. Journal of Banking \& Finance, 31, 1101-1133.

Ito, H. (2006). Financial Development and Financial Liberalization in Asia: Thresholds, Institutions and The Sequence of Liberalization. North American Journal of Economics and Finance, 17, 303-327.

Jalil, A., Feridun, M., \& Ma, Y., (2010). Finance-Growth Nexus in China Revisited: New Evidence from Principal Components and ARDL Bounds Tests. International Review of Economics and Finance, 19, 189-195.

Karakaya, A., \& Er, B. (2013). Noninterest (Nonprofit) Income and Financial Performance at Turkish Commercial and Participation Banks. International Business Research, 6, 106.

Karim, B. K., Sami, B. A., \& Hichem, B. K. (2010). Bank-Specific, Industry-Specific and Macroeconomic Determinants of African Islamic Banks' Profitability. International Journal of Business and Management Science, 3, 39-56.

Khan, F. (2010). How 'Islamic' is Islamic Banking? Journal of Economic Behavior $\mathcal{E}$ Organization, 76, 805-820. 
Kwan S.H. (1998). Securities Activities by Commercial Banking Firms' Section 20 Subsidiaries: Risk, Return and Diversification Benefits. Federal Reserve Bank of San Francisco, working paper 98-10.

Laeven, L., \& Levine, R. (2007). Is There a Diversification Discount in Financial Conglomerates? Journal of Financial Economics, 85,331-367.

Law, Siong Hook., \& Azman-Saini, W.N.W., \& Ibrahim, Mansor H. (2013). Institutional Quality Thresholds and The Finance - Growth Nexus. Journal of Banking and Finance, Elsevier, 37, 5373-5381.

Lepetit, L., Nys, E., Rous, P., \& Tarazi, A. (2008). Bank Income Structure and RiskAn Empirical Analysis of European Banks. Journal of Banking and Finance, 32, 1452-1467.

Lin S.L., Wu S., Penm J.H.W. and Terrell R.D. (2005). The Relationship and Causality Testing between Diversification, Risk and Financial Performance: Empirical Examination in Taiwan's Banking Industry. International Journal of Services Technology and Management, 6, 556-575.

Masruki, R., Ibrahim, N., Osman, E., \& Abdul Wahab, H. (2010). Financial Performance of Malaysian Islamic Banks Versus Conventional Banks. Journal of Business and Policy Research, 6, 67-79.

Molyneux, P., \& Yip, J. (2013). Income Diversification and Performance of Islamic Banks. Journal of Financial Management, Markets and Institutions, 1, 47-66.

Moshirian, F., \& Van der Laan, A. (1998). Trade in Financial Services and The Determinants of Banks' Foreign Assets. Journal of Multinational Financial Management, 8, 23-38.

Moyo, J., Nandwa, B., Odour, J. (2014) Financial Sector Reforms, Competition and Banking System Stability in Sub-Saharan Africa. Paper presented at the IMF/ DFID Conference.

Noman, A. H. M., Gee, C. S., \& Isa, C. R. (2018). Does Bank Regulation Matter On the Relationship Between Competition and Financial Stability? Evidence from Southeast Asian Countries. Pacific-Basin Finance Journal, 48, 144-161.

Pennathur, A. K., Subrahmanyam, V., \& Vishwasrao, S. (2012). Income Diversification and Risk: Does Ownership Matter? An Empirical Examination of Indian Banks. Journal of Banking and Finance, 36, 2203-2215.

Petria, N., Capraru, B., \& Ihnatov, I. (2015). Determinants of Banks' Profitability: Evidence from EU 27 Banking Systems. Procedia Economics and Finance, 20, 518524.

Poghosyan, T. (2013). Financial Intermediation Costs in Low Income Countries: The Role of Regulatory, Institutional, and Macroeconomic Factors. Economic Systems, 37, 92-110.

Rahaman, M.M., (2011), Access to Financing and Firm Growth. Journal of Banking and Finance, 35, 709-723.

Rajan, R. G. \& Zingales, L. (1998). Financial Dependence and Growth. American Economic Review, 8, 559-586.

Ramasastri A.S., Samuel A., \& Gangadaran S. (2004). Income Stability of Scheduled Commer- cial Banks: Interest Vis-à-Vis Non-Interest Income. Economic and Political Weekly, 39, 1311-1316.

Rogers, K., \& Sinkey, J. F. (1999). An Analysis of Nontraditional Activities at US Commercial Banks. Review of Financial Economics, 8, 25-39. 
Sadique, M. A. (2010). Islamic Bank's Dilemma between Ideals and Practice: Debt or Equity. Global Journal of Management and Business Research, 10.

Sanya S. and Wolfe S. (2011) 'Can Banks in Emerging Economies Benefit from Revenue Diversification?', Journal of Financial Services Research, 40, 79-101.

Shahimi, S., Ismail, A. G. B., \& Ahmad, S. B. (2006). A Panel Data Analysis of Fee Income Activities In Islamic Banks. Journal of King Abdulaziz University: Islamic Economics, 19, 22-36.

Smaoui, H., \& Salah, I. B. (2011). Profitability of Islamic Banks in The GCC Region. Annual Paris Conference on Money, Economy and Management, Paris, France.

Smith R., Staikouras C. and Wood G. (2003) Non-Interest Income and Total Income Stability, Bank of England Working Paper no. 198.

Soedarmono, W., Machrouh, F., \& Tarazi, A. (2013). Bank Competition, Crisis and Risk Taking: Evidence from Emerging Markets in Asia. Journal of International Financial Markets, Institutions and Money. 23, 196-221.

Stiroh, K. J., \& Rumble, A. (2006). The Dark Side of Diversification: The Case of US Financial Holding Companies. Journal of Banking and Finance, 30, 2131-2161.

Stiroh, K.J., (2004). Diversification in Banking: Is Noninterest Income the Answer? Journal of Money, Credit and Banking, 36, 853-882.

Zhang, Y., (2010). Analysis of the Systematic Risk of Financial Institution in Modern Finance Evolution, International Journal of Economics and Finance, 2, 234-237

Zahavi, T., \& Lavie, D. (2013). Intra-Industry Diversification and Firm Performance. Strategic Management Journal, 34, 978-998. 
This page is intentionally left blank 